\title{
DO DIREITO FUNDAMENTAL DE ACESSO À JUSTIÇA*
}

\section{OF THE BASIC RIGHT OF ACCESS TO JUSTICE}

\author{
Mauro Vasni Paroski
}

\begin{abstract}
Resumo: $\mathrm{O}$ acesso à justiça é aqui estudado como direito fundamental. $\mathrm{O}$ artigo tem por escopo a conceituação dessa garantia e a identificação dos principais problemas que apresenta. Analisa a tutela dos direitos e oferece propostas visando aperfeiçoar o sistema de solução de controvérsias. Sustenta que a ordem jurídica justa é a que consagra os valores eleitos pela sociedade na Constituição e que a proteção jurisdicional aos direitos deve se harmonizar com os objetivos, valores e princípios constitucionais. Afirma que é necessário estimular os meios alternativos de solução de conflitos jurídicos, como a arbitragem, a mediação e a conciliação.
\end{abstract}

Palavras-chave: Acesso. Constituição. Fundamental. Justiça. Tutela.

Abstract: The access to justice is here studied as right basic. The article has for target the conceptualization of this guarantee and the identification of the main problems that presents. It analyzes the protection of the rights and offers proposals aiming at to perfect the system of solution of controversies. It supports that the joust juridical order is the one that consecrates the elect values for the society in the Constitution and that the jurisdictional protection to the rights must harmonize with the objectives, values and principles constitutional. It affirms that it is necessary to stimulate the alternative ways of solution of legal conflicts, as the arbitration, the mediation and the conciliation.

Keywords: Access. Constitution. Basic. Justice. Protection.

\footnotetext{
Este artigo é síntese da dissertação defendida no ano de 2006 no Mestrado em Direito Negocial da Universidade Estadual de Londrina (UEL), sob orientação do professor Dr. Lourival José de Oliveira.

"* Especialista em Direito Civil e Direito Processual Civil e Mestre em Direito Negocial, área de concentração em Direito Processual Civil, ambos pela Universidade Estadual de Londrina, PR. Juiz do Trabalho desde 1995. Titular da Vara do Trabalho de Porecatu, PR. E-mail: paroski@gmail.com ou paroski@pop.com.br.
} 


\section{INTRODUÇÃO}

A solução dos conflitos de interesses, pelo exercício da jurisdição, traduz-se em atividade estatal de indiscutível essencialidade, prestada precipuamente através do Poder Judiciário, o que não exclui a possibilidade do emprego de outras alternativas não-estatais, desde que adequadas e validadas pela ordem jurídica, como a arbitragem, a mediação e a conciliação.

O Poder Judiciário brasileiro sempre foi lento e ineficiente, repercutindo na falta de efetividade do processo jurisdicional. Esta situação compromete a realização dos direitos e gera a desconfiança da população em suas instituições. A maioria das críticas nessa direção é merecida e deve servir para a reflexão.

O acesso à justiça não se limita à dimensão puramente formal, mas, vai mais além, envolvendo a efetividade dos direitos materiais e a concretização das garantias processuais constitucionais. Assume papel importante o estudo das limitações desse direito. Entretanto, além da análise crítica e da identificação dos principais problemas, torna-se imprescindível a formulação de propostas.

\section{OS DIREITOS FUNDAMENTAIS E A CONSTITUIÇÃO}

Há que se ter em mente uma noção, ainda que bastante limitada, sobre o que deve ser entendido por direitos fundamentais, que tanto podem ser estudados como uma teoria, isto é, abstratamente, dissociados de um ordenamento jurídico vigente em certo tempo e lugar ou, podem ser estudados de acordo com o tratamento que lhes é dispensado por uma ordem constitucional concreta, em determinado lugar e tempo.

O jusnaturalismo prega que há direitos naturais do homem, colocando-o no centro de seus princípios, pois, referidos direitos são inatos ao ser humano e anteriores ao surgimento do Estado, independentes de um ordenamento jurídico estatal, que seria a legitimação das disposições reguladoras da vida em sociedade.

Dentre esses direitos estão a liberdade, a igualdade e a dignidade, ocupando uma posição que lhes colocam na base da construção do restante dos direitos e servindo de fonte de inspiração para o aperfeiçoamento do ordenamento jurídico, priorizando sempre a pessoa humana.

A corrente juspositivista, por sua vez, tem concepção distinta, que de certo modo se opõe à concepção jusnaturalista, ao sustentar que as necessidades fundamentais do homem, individual ou socialmente considerado, não se confundem com o que se deve entender por Direito.

Para essa corrente, somente constituem Direito as regras assim reconhecidas por um ordenamento imperativamente ditado pelo Estado, a quem competirá 
estabelecer quais são as normas que têm qualificação jurídica capazes de gerar direitos e obrigações, além de atrair sua imposição por um poder constituído pelo Estado com esta finalidade, quando não observadas espontaneamente por seus destinatários. Os direitos fundamentais, portanto, nascem enquanto são reconhecidos como direitos e como fundamentais pela Constituição (KELSEN, 2003, p. 21-7).

$\mathrm{Na}$ perspectiva positivista da concepção material, somente são básicos ou fundamentais os direitos (interesses ou bens) reconhecidos e tutelados pela ordem jurídica, segundo o seu sistema instrumental. Na perspectiva não positivista, não se valoriza o reconhecimento e a tutela conferidos pela ordem jurídica estabelecida, mas sim, encontram-se os fundamentos desta espécie de direito nas aspirações morais ou nas necessidades humanas maiores, que dizem respeito à dignidade do homem, como a igualdade, liberdade, segurança e propriedade, como também aos seus interesses sociais e econômicos. Tem suas base no jusnaturalismo e na teologia (SAMPAIO, 2004, p. 24).

Relativamente às concepções formais, considerando suas perspectivas teóricas, vislumbram em certos direitos alguns atributos com caráter de universalidade que os qualificam de fundamentais, assim compreendidos enquanto próprios de todos os homens, independentemente de sua origem, etnia, raça, cor, sexo, religião e cultura, isto é, são fundamentais porque essenciais a existência digna de todos os seres humanos, como os direitos à liberdade, à igualdade, à vida, à integridade física, à saúde, à subsistência, à assistência aos desvalidos e à educação, e ainda, as garantias penais e processuais, incluindo o acesso à justiça como meio de solucionar os conflitos de interesses, dado o monopólio instituído em favor do Estado (SAMPAIO, 2004, p. 27-9).

Para o estudo do acesso à justiça, enquanto garantia constitucionalizada (Art. 5a inc. XXXV), melhor se ajusta, quanto aos direitos fundamentais, a concepção material de uma perspectiva positivista. O Artigo 5 $5^{\underline{a}}$ § $2^{\underline{a}}$, da Constituição da República adota conceito materialmente aberto sobre esta categoria de direitos. Viabiliza, assim, a possibilidade de identificação de direitos fundamentais em outros setores da própria Constituição, no ordenamento jurídico infraconstitucional e nos tratados internacionais incorporados à ordem jurídica interna.

\section{O QUE SE DEVE ENTENDER POR ACESSO À JUSTIÇA}

O acesso à justiça há algum tempo tem figurado nos catálogos de direitos fundamentais, assim reconhecidos pelas constituições e por declarações de direitos nacionais e internacionais, em sentido bastante amplo, e não como mero direito 
de acesso ao Poder Judiciário. Pode ser visto de mais de um ângulo e seu significado certamente sofrerá variação conforme o ordenamento jurídico constitucional em concreto em que o tema for situado.

$\mathrm{Na}$ doutrina nacional tem predominado, pelo menos nos últimos vinte anos, o entendimento de que o acesso à justiça não significa somente ter mero acesso aos tribunais, mas sim, obter concretamente a tutela jurisdicional quando se tem razão. Mas não basta, ainda assim, em grande parte dos casos, a obtenção de solução jurisdicional para os conflitos de interesses, pois, esta nem sempre é adequada, tempestiva e efetiva.

Além disso, o acesso aos meios estatais de solução de conflitos para a tutela dos direitos lesados ou ameaçados de lesão não exclui outras formas de pacificação social e de solução de conflitos que melhor atendam aos interessados. O ordenamento jurídico pode colocar à disposição das pessoas outras alternativas, que não a jurisdicional, a serem empregadas voluntariamente por elas, quando protagonistas de conflitos de interesses, a exemplo da mediação e da arbitragem privadas.

Barreiras hão que ser rompidas, com a facilitação não apenas do ingresso em juízo, mas também pelo fornecimento de meios (processuais, materiais, financeiros etc.) adequados durante todo o desenvolvimento do procedimento. Ter acesso à justiça, notadamente para a população pobre, significa, por exemplo, redução de custos, encurtamento de distâncias, duração razoável do processo, diminuição de oportunidades de impugnação às decisões jurisdicionais (otimização do sistema recursal) e efetiva participação na relação processual.

O acesso à justiça talvez seja o mais básico dos direitos fundamentais, pois que é através do seu exercício que outros direitos fundamentais podem ser assegurados quando violados, pela imposição de sua observância pelos órgãos estatais encarregados da jurisdição.

Para Cappelletti e Garth (2002, p. 8):

A expressão 'acesso à justiça' é reconhecidamente de difícil definição, mas serve para determinar duas finalidades básicas do sistema jurídico - o sistema pelo qual as pessoas podem reivindicar seus direitos e/ou resolver seus litígios sob os auspícios do Estado. Primeiro, o sistema ser igualmente acessível a todos; segundo, ele deve produzir resultados que sejam individual e socialmente justos. [...] uma premissa básica será a de que a justiça social, tal como desejada por nossas sociedades modernas, pressupõe o acesso efetivo.

O acesso à justiça é entendido por Canotilho (2003, p. 433, 492) do seguinte modo: 
Em termos gerais - e como vem reiteradamente afirmando o Tribunal Constitucional na senda do ensinamento de Manuel de Andrade -, o direito de acesso aos tribunais reconduz-se fundamentalmente ao direito a uma solução jurídica de actos e relações jurídicas controvertidas, a que se deve chegar um prazo razoável e com garantias de imparcialidade e independência possibilitando-se, designadamente, um correcto funcionamento das regras do contraditório, em termos de cada uma das partes poder deduzir as suas razões (de facto e de direito), oferecer as suas provas, controlar as provas do adversário e discretear sobre o valor e resultado de causas e outras". [...] Significa isto que o direito à tutela jurisdicional efectiva se concretiza fundamentalmente através de um processo jurisdicional eqüitativo - due process. [...] O direito ao processo eqüitativo está hoje positivamente consagrado no art. $20^{\underline{a}}$ da CRP; no art. $6^{\underline{a}}$ da Convenção Européia dos Direitos do Homem; no art. 14 $4^{a}$ do Pacto Internacional Relativo aos Direitos Civis e Políticos e no art. 10ำ da Declaração Universal dos Direitos do Homem.

Reservar para si, como fez o Estado, o monopólio da justiça, e ao mesmo tempo, como conseqüência lógica, proibir a realização da justiça pelas próprias mãos, como é intuitivo, importa na necessidade da implantação de meios eficazes de solução dos conflitos de interesses.

O pleno acesso a esses meios também há que ser assegurado pela ordem constitucional, que deve zelar pela criação de instrumentos processuais que tenham aptidão de efetivamente realizar este propósito maior, de atuar pela manutenção da paz social, que se atinge quando se soluciona dentro de certos parâmetros de razoabilidade os conflitos jurídicos individuais e coletivos.

O acesso à justiça traduz a idéia de uma garantia presente em dado ordenamento jurídico, através da qual o Estado assegure igualitariamente a todas as pessoas meios capazes de gerar decisões que levem à solução justa dos conflitos de interesses, individuais e coletivos.

\section{A ORDEM JURÍDICA JUSTA}

A Constituição da República ao arrolar alguns princípios processuais, que considerou fundamentais, coerentes com o regime democrático, demonstra que o direito material e o direito processual são indissociáveis, influenciando-se reciprocamente, não prescindindo o primeiro do segundo e vice-versa (MESQUITA, 2002, p. 139).

A ordem constitucional deve garantir uma tutela jurisdicional adequada a cada caso concreto, como corolário do acesso à justiça e o quanto possível deve assegurar às partes uma igualdade real e não meramente formal através da possibilidade do ajuizamento da demanda. 
Ensina Ramos (2000, p. 38-9), que:

Atualmente já está vencida a idéia de que a mera possibilidade de acesso aos órgãos judiciais seja a verdadeira significação da acepção jurídica de acesso à justiça. Hoje, muito mais do que o acesso aos tribunais, de fundamental importância mas não apto a esgotar todas as vias política e socialmente desejáveis de resolução de conflitos, o fenômeno do acesso à justiça deve ser compreendido como a possibilidade material do ser humano conviver em uma sociedade onde o direito é realizado de forma concreta, seja em decorrência da manifestação soberana da atuação judiciária do organismo estatal, seja, também, como reflexo da atuação das grandes políticas públicas a serem engendradas pela respectiva atuação executiva, não olvidando-se, é claro, o escorreito regramento a ser imprimido pela atuação legiferante. Tudo isso, vale dizer, é de suma importância para a efetivação de uma realidade tão mais democrática quanto justa, onde se possa ter a irrefragável certeza de uma atuação garantista que prestigie a vida, a dignidade e o respeito incorruptível aos direitos fundamentais do homem. Enfim, o enaltecimento do valor da justiça como referência a ser seguida.

A aplicação do princípio do acesso à justiça implica em um processo justo e imparcial, mas não só isso, devendo ser incluída a garantia de igualdade de oportunidade às partes litigantes, com participação efetiva e adequada na relação processual, o que se coaduna com o regime democrático e com o exercício da cidadania.

Para Watanabe (1988) o acesso à justiça não se limita à mera provocação do Poder Judiciário, mas importa, fundamentalmente, no "direito de acesso à ordem jurídica justa”, e para que tal desiderato seja alcançado, faz-se mister a presença dos seguintes elementos:

a) direito à informação;

b) adequação entre a ordem jurídica e a realidade sócio-econômica do país;

c) direito a uma justiça adequadamente organizada e formada por juízes inseridos na realidade social e comprometidos com o objetivo de realização da ordem jurídica justa;

d) direito a pré-ordenação dos instrumentos processuais capazes de promover a efetiva tutela de direitos;

e) direito à remoção de todos os obstáculos que se anteponham ao acesso;

f) efetivo acesso à justiça com tais características.

A idéia de um processo de resultados, de natureza instrumental, não desfruta de unanimidade na doutrina, dela discordando, por exemplo, Calmon de Passos (2001, p. 1-14), que nitidamente defende a conservação absoluta das garantias 
processuais constitucionais dos litigantes (sem qualquer limitação em prol de outros valores), como conseqüência do regime democrático de direito e do princípio da separação dos poderes, porque somente o legislador tem legitimidade para eleger dentre as opções possíveis as que irão reger a sociedade, às quais deve se curvar o Judiciário no exercício da função jurisdicional.

Calmon de Passos (2001, p. 1-14) condena as reformas processuais que tendem a priorizar os interesses do autor em detrimento dos interesses do réu, colocando em posição secundária os resultados e a efetividade da prestação jurisdicional e entendendo que a prevalência do princípio da instrumentalidade serve de incentivo à exacerbação da litigiosidade e aos comportamentos inescrupulosos em juízo, favorecendo o arbítrio e a falta de ética e de técnica das decisões jurisdicionais.

Em que pese este posicionamento vigoroso, não são poucos os processualistas que se filiam a outra corrente de pensamento, que se opõe a ora mencionada, a exemplo de Dinamarco (2003), Watanabe (2000) e Bedaque (2003ab), sustentando que o processo jurisdicional deve produzir resultados efetivos, solucionando os conflitos, restabelecendo a paz social e entregando concretamente a quem tem razão o bem da vida pretendido.

Enfim, um processo capaz de eliminar lesão atual ou iminente a direitos e interesses juridicamente protegidos, gerando decisões que projetem efeitos na vida das pessoas a quem a tutela é prestada. Para essa doutrina, o processo não tem um escopo que se esgota em si mesmo, mas deve servir à sociedade, ao Estado e aos indivíduos.

\section{A TUTELA DE DIREITOS}

$\mathrm{O}$ acesso à justiça consiste em um tema que guarda íntima relação com as questões pertinentes à jurisdição, pois, é através do exercício dessa última, como regra, que o direito não observado espontaneamente é cumprido, pela coação exercida pelo Estado contra o titular do correspondente dever jurídico.

Tal se sucede, com freqüência, quando a norma elaborada pela autoridade competente está em desconformidade com os valores tidos como importantes pela sociedade, quando ignora o sentimento coletivo de justiça, ou mesmo quando pretende exigir um comportamento das pessoas que não se ajusta à realidade constatada no momento em que deve ser aplicada ou simplesmente cumprida.

A tutela jurídica constitui-se na própria proteção dada aos direitos e interesses pelo ordenamento jurídico, distinguindo-se da tutela jurisdicional, em face de que esta é alcançada somente pela atuação do Estado, através do devido processo legal, depois de regularmente proposta a demanda, visando um provimento que seja adequado a essa tutela. 
Quando as relações intersubjetivas são objeto de regulamentação pelo Estado, através de normas imperativas editadas pelo Poder competente, tornam-se relações jurídicas, aptas a produzirem direitos e obrigações, consistindo no que é denominado de direito substancial. À par do direito substancial há também o direito processual, que juntos formam os dois planos do ordenamento jurídico. O segundo tem a função de fazer atuar o primeiro, quando não é observado espontaneamente pelos seus titulares.

Na precisa lição de Bedaque (2003a, p. 11):

[...] O direito processual é formado por regras, cuja finalidade é garantir que a norma substancial seja atuada, mesmo quando o destinatário não o faça espontaneamente. [...] Tem-se, portanto, como direito processual aquele conjunto de princípios e regras que regulam o exercício da jurisdição, da ação, da defesa e do processo. Essas normas estão dispostas na Constituição da República, nas Constituições estaduais, no Código de Processo Civil, em leis extravagantes e nas leis de organização judiciária. É a noção de direito processual determinada por seus elementos fundamentais, suficiente para distingui-lo do direito material.

Não é recomendável, assim, identificar tutela jurídica com tutela jurisdicional, por serem expressões que se distinguem quanto ao seu âmbito de aplicação, sem embargo de divergências doutrinárias a respeito dos seus significados.

O termo 'tutela' significa proteção. Ao se ligar ao termo 'jurisdicional', o único significado possível é o de que se trata de uma proteção conferida pelo Estado, através do exercício da jurisdição, e conseqüentemente, do processo, ao litigante a quem se reconhece estar com a razão.

Portanto, afirma-se com tranqüilidade que a doutrina não diverge quanto ao entendimento de que a tutela jurídica e a tutela jurisdicional não são a mesma coisa. A primeira significa a proteção conferida pelo ordenamento jurídico aos direitos das pessoas (direito subjetivo ou atos lícitos), através de normas materiais que têm por objetivo regular diretamente a atribuição de bens e a determinação de condutas humanas. A tutela jurídica, portanto, tem por finalidade conferir proteção aos direitos subjetivos ou aos atos lícitos.

Resumidamente, pode-se dizer que tutela jurídica é a proteção conferida pelo Estado, através das disposições contidas no ordenamento jurídico, seja através de um órgão administrativo, seja por meio de um órgão jurisdicional.

Tem-se a expectativa de que haja o cumprimento voluntário das disposições integrantes do ordenamento jurídico, mas, sabidamente, nem sempre isso se sucede, e diante da violação da lei, incumbe ao Estado assegurar a atuação do 
direito objetivo, mediante a imprescindível provocação do interessado, surgindo o que se denomina de tutela jurisdicional.

Belinetti (1996, p. 98) afirma que:

A tutela jurídica significa a proteção do Direito para os direitos subjetivos e qualquer forma de atuar lícito, enquanto que a tutela jurisdicional significa a proteção do Estado, com base no Direito, para esses direitos e atividades lícitas, quando envolvidos em um conflito jurídico de interesses.

Infere-se, assim, que a tutela jurisdicional é espécie do gênero tutela jurídica, que consiste na proteção do Estado ao direito subjetivo, desde que provocado pelo respectivo titular, tendo por finalidade principal a atuação da lei aos casos concretos. Quanto ao objeto da tutela jurisdicional, predomina o entendimento de que a proteção se destina aos direitos subjetivos ou qualquer forma de atuar lícito.

\section{MEIOS ALTERNATIVOS DE SOLUÇÃO DE CONFLITOS}

Tem sido recorrente na doutrina o reconhecimento das deficiências dos meios estatais de solução de conflitos, com propostas de estímulo, como uma necessidade das sociedades contemporâneas, às vias alternativas de pacificação social. As principais delas, prestigiadas pelo ordenamento jurídico, são a arbitragem, a mediação e a conciliação.

A arbitragem é tratada como meio alternativo, pela qual a decisão tomada pelo árbitro eleito pelas partes põe termo ao conflito jurídico de interesses, sendo sustentado por renomada doutrina, a exemplo de Carmona (1993), que esta decisão tem aptidão para a produção dos efeitos da coisa julgada, sendo facultativa a sua instituição e, assim, não se choca com a garantia constitucional da jurisdição, prevista pelo Artigo 5 ${ }^{\mathrm{a}}$, inciso XXXV, da Constituição.

A Lei $n^{\underline{a}}$ 9.307, de 23 de setembro de 1996, que disciplina a arbitragem, não afasta a jurisdição estatal, pois, se o fizesse, seria inconstitucional. Na verdade, este meio de solução de conflitos é posto à disposição das pessoas, que são livres para, voluntariamente, elegê-lo como alternativa àquela, mas não estão obrigadas a fazê-lo. O que não se admite é o arrependimento posterior com a instituição da cláusula de compromisso ou o inconformismo com o laudo arbitral, submetendo ao Judiciário litígio já resolvido. Evidente que o controle da legalidade do procedimento arbitral continua sendo atribuição do Judiciário, que poderá ser provocado por quaisquer das partes envolvidas no litígio.

A mediação e a conciliação não são meios que têm o condão de substituir a jurisdição estatal na solução de problemas jurídicos, nem se confundem com a 
arbitragem, tratando-se de métodos ou técnicas que podem ser empregados para facilitar a tarefa de se encontrar a solução mais adequada para o litígio, diretamente pelas partes ou com o auxílio de um terceiro, tanto judicialmente como extrajudicialmente, trazendo como corolário a pacificação social, quando levam à eliminação do conflito de interesses.

A transação, que também é uma forma de conciliação, consiste em instituto que tem por finalidade a prevenção ou a terminação de litígios, importando em contrato bilateral envolvendo concessões recíprocas, podendo ser materializada em escritura pública ou mediante termo nos autos quando se referir aos direitos discutidos em juízo, revestindo-se de eficácia jurídica capaz de serenar os ânimos e restabelecer a paz entre os contendores.

O emprego desses meios deve ser incentivado pela ordem jurídica, porque podem contribuir decisivamente para a diminuição do excesso de demandas, em benefício do universo da população, tornando mais célere e efetiva a prestação jurisdicional.

\section{ALGUNS OBSTÁCULOS AO ACESSO À JUSTIÇA}

As dificuldades de acesso à justiça não se limitam à dimensão interna do sistema estatal de solução de controvérsias jurídicas ou de garantia de exercício de direitos, denominado de sistema processual, mas também têm origem externa, havendo inúmeros fatores exoprocessuais que interferem negativamente na consecução do objetivo de se garantir o pleno acesso aos direitos e, particularmente, à justiça.

Os óbices dessa natureza residem em áreas externas ao sistema processual, mais precisamente nos campos político, social e econômico-financeiro.

Politicamente, o Estado elege opções dentre as existentes, especialmente quando se mostram incompatíveis entre si, num contexto que procure equilibrálas.

Quanto ao aspecto social, destacam-se as oportunidades oferecidas pelo Estado aos sujeitos, de maior ou menor grau, no que se refere à possibilidade de postular judicialmente o exercício de direitos, sua preservação ou restauração.

No campo econômico-financeiro têm lugar a estrutura material em que se encontram os órgãos jurisdicionais e as condições materiais de acesso a eles pelos usuários dos serviços judiciários.

As decisões pertinentes à política judiciária, relacionadas com a organização e divisão judiciárias, incluindo a criação de comarcas, de varas especializadas, de novas varas e da distribuição de competências entre elas, devem levar em consideração os anseios e as aspirações dos jurisdicionados, baseadas em critérios 
objetivos, técnicos, que de fato atendam às necessidades dos usuários do sistema jurisdicional, com o encurtamento de distâncias e a diminuição de custos, como fatores de facilitação do acesso à justiça.

No campo social são vários fatores que podem comprometer a credibilidade e a eficiência do sistema estatal de solução dos litígios, funcionando como elementos inibidores do acesso à justiça, o que pode ser verificado tanto quanto a aceitação social da justiça das decisões legislativas na elaboração do direito objetivo, da falta de efetividade (ou eficácia social) das normas jurídicas, da falta de eficiência dos instrumentos processuais para a preservação ou o restabelecimento do direito lesado e no baixo índice de confiabilidade nas instituições públicas e seus integrantes.

Outro aspecto importante, quanto à falta de confiança da população nas instituição judiciárias, é a impunidade que grassa pelo país quando se trata de sancionar, com firmeza, a conduta dos responsáveis pelos delitos de graves repercussões sociais, políticas e econômicas, muitas vezes envolvendo sonegação de tributos, fraudes milionárias nos sistemas oficiais de previdência social, desvio de verbas públicas, corrupção em grande escala, remessa ilegal de recursos financeiros ao exterior, obtenção de recursos financeiros através de atividades ilícitas e fraudes eleitorais, enfim, os chamados delitos de "colarinho branco", em que os envolvidos invariavelmente são empresários e autoridades públicas, incluindo os membros do Legislativo, Executivo e Judiciário.

A ignorância da população sobre os direitos consagrados pela ordem jurídica é fator que, por si só, reduz sensivelmente o acesso à justiça. A falta de informação leva as pessoas a não procurarem tutela jurisdicional para seus direitos quando lesados, atuando, em certa medida, como fator de exclusão social, pois que muitas vezes somente com o êxito de uma demanda judicial é possível o exercício de determinados direitos negados pelo titular do dever jurídico.

Uma das maiores, senão a maior, das limitações do acesso à justiça reside na falta de condições econômico-financeiras da maior parte da população para custear as despesas com a movimentação da máquina judiciária, restringindo seu acesso aos órgãos jurisdicionais, o que ocorre não apenas para o ingresso em juízo, mas especialmente durante o desenvolvimento dos atos do procedimento, desestimulando-a a buscar remédio para os problemas jurídicos que a aflige.

A melhoria da qualidade de vida da população passa pela implantação de políticas públicas efetivas, pela mais justa distribuição de renda, pela redução da concentração de riquezas, pelo crescimento econômico, pelo planejamento racional das atividades públicas, enfim, por um número quase sem fim de condutas afetas aos três níveis de poder, no âmbito federal, estadual e municipal. 
Inadmissível que num país como o Brasil, em que a maior parte da população é carente, fique esta excluída, à margem da justiça, que se converteria em privilégio de poucos afortunados.

Esta realidade, que de certo modo revela a incapacidade do Estado em cumprir satisfatoriamente seus deveres, não se coaduna com o estado de direito, pois, é próprio deste garantir efetivamente a igualdade, de modo que os pobres devem ter as mesmas oportunidades que os ricos para ingressarem em juízo postulando tutela jurisdicional aos seus direitos, o que importa em reconhecer a necessidade de adoção de medidas que garantam a igualdade material, real, e não apenas formal, de todos os indivíduos, independentemente de sua condição social e de sua capacidade econômico-financeira.

Como dito alhures, o Estado assumiu para si o monopólio da justiça, sendo seu dever, por força da própria Constituição, prestar jurisdição a todos que dela necessitarem, assegurando aos mais pobres os meios e os instrumentos para que tal se torne realidade, com a instituição de mecanismos de assistência judiciária ampla e a implantação de defensorias públicas, que possam funcionar com a mesma eficácia que nos demais casos em que os litigantes têm condição econômica para fazer frente às despesas do litígio.

As despesas processuais, mormente na Justiça Comum Estadual, nas regiões (em sua maioria) em que os serviços auxiliares do juízo (serventias judiciais e extrajudiciais) são explorados por particulares, consistem em destacada limitação ao acesso à justiça, mesmo quando concedido o benefício da assistência judiciária gratuita àqueles que dela necessitam, sendo incontestável que nesses casos não há empenho e boa vontade dos serventuários e oficiais de justiça para que o processo tramite de forma célere.

Muitas vezes alguns estudiosos que têm se ocupado dos problemas relativos ao acesso à justiça têm pregado a extinção das custas processuais, para melhor viabilizar a efetivação desse direito, a exemplo de Nalini (1994, p. 33-4), idéia que não parece acertada, sendo talvez o caso de se pensar em modificação em sua disciplina, exigindo-as apenas do vencido na demanda, ao final do procedimento, mediante execução se não forem pagas espontaneamente, isto é, sem condicionar a realização dos atos processuais à sua satisfação prévia, como se dá atualmente. Desta exigência deve ser dispensado o beneficiário da assistência judiciária gratuita, arcando o Estado com o pagamento das despesas realizadas por particulares, a exemplo dos serviços prestados pelos peritos, quando aquele fosse vencido na demanda, cabendo o pagamento ao seu adversário, em caso contrário.

A falta de recursos financeiros, sua insuficiência, além de ser um problema afeto à população mais pobre, também atinge os próprios órgãos jurisdicionais, 
pois que não obstante a autonomia financeira dos tribunais, que têm relativa liberdade para elaborarem seus próprios orçamentos assegurada pela Constituição, não elimina certa dependência política em relação aos Poderes Executivo e Legislativo, que na prática ainda existe, repercutindo negativamente na sua atuação administrativa e jurisdicional, comprometendo a eficiência de todo o sistema, em prejuízo dos seus usuários. ${ }^{1}$

O $\S 1^{\underline{a}}$ do Artigo 99, da Constituição (CAHALI, 2004, p. 79), reza que “os tribunais elaborarão suas propostas orçamentárias dentro dos limites estipulados conjuntamente com os demais Poderes na lei de diretrizes orçamentárias”.

A exigência de consenso entre os três Poderes retira de certo modo parte da autonomia financeira dos tribunais.

Outro fator importante consiste na inadequada e irracional aplicação dos recursos financeiros destinados ao Poder Judiciário. Na maior parte dos casos são frágeis e ineficientes os sistemas de administração desses recursos, que se mostram obsoletos e anacrônicos, não se identificando na atuação dos dirigentes dos tribunais, em sua maioria, capacidade de aplicação de técnicas eficazes de gerenciamento administrativo-financeiro.

Talvez uma das causas que explique esta situação, em grande parte, seja o fato de que os dirigentes dos tribunais, conquanto preparados para a função jurisdicional, não foram preparados para a função administrativa, na qual se revelam, via de regra, um desastre, justificando parcialmente as críticas que a todo instante estão estampadas pelos meios de comunicação. A recente criação do Conselho Nacional de Justiça tende a modificar esse quadro de quase fracasso dos sistemas vigentes de gerenciamento de recursos na maioria dos tribunais pátrios.

Várias outras limitações ao acesso à justiça se relacionam mais de perto à própria prestação jurisdicional, considerando-se fatores como a eficiência do sistema de assistência judiciária aos necessitados, a não instalação das defensorias públicas, a própria postura do julgador em relação ao ordenamento jurídico positivo na interpretação e aplicação das suas normas e a inadequação do processo clássico à tutela dos interesses transindividuais.

Também se mostram relevantes a habilidade dos interessados no manejo do processo, as técnicas processuais postas à disposição da atividade jurisdicional para a melhor solução dos litígios, a questão da morosidade processual e da eficácia das decisões jurisdicionais, a elevada litigiosidade do poder público e o excesso de demandas e de oportunidades para oferecimento de recursos.

${ }^{1}$ Artigo 99, da Constituição da República: "Ao Poder Judiciário é assegurada autonomia administrativa e financeira”. 


\section{PROPOSTAS}

As pesquisas realizadas para viabilizar o estudo do tema e que resultaram nesse trabalho, mostram a necessidade de implementação de um conjunto de medidas que possam tornar possível o acesso à justiça como uma realidade, abandonando a sua condição de mero discurso acadêmico ou enunciado formal, para se fazer como ser, adquirindo concretude.

Pouco se acrescenta, mas pelo contrário, torna o trabalho quase inteiramente inútil, se o seu objetivo se limitar a unicamente investigar as causas da ineficiência do sistema estatal de solução de conflitos de interesses, identificando e criticando os pontos de estrangulamento, mas não apresentando propostas acerca do que se pode fazer para tornar efetivo o acesso à justiça.

Dentre as possíveis soluções, ad referendum do Congresso Nacional e das autoridades administrativas competentes para impor as mudanças que se apresentam como imprescindíveis, de modo coerente com a explanação feita em relação ao acesso à justiça, sem embargo de que algumas medidas exigem alterações legislativas e até mesmo emendas constitucionais para sua implementação, podem ser apontadas como as principais delas:

1. Melhor distribuição dos órgãos jurisdicionais e dos magistrados no território nacional, conforme as necessidades de cada região, observandose suas singularidades, inclusive a natureza dos litígios, estabelecendo-se uma estimativa com base nas experiências já realizadas, dos tipos de litígios de maior freqüência (direito do trabalho, direito de família, direito penal, direito previdenciário, direito tributário etc.), para efeito de aprimoramento na prestação jurisdicional em cada localidade;

2. Informatização dos serviços, em todos os ramos do Judiciário e em todas as localidades, criando-se um sistema de integração entre eles, para obtenção de informações e agilização de prática de determinados atos processuais, a exemplo de cumprimento de intimações, notificações e cartas precatórias, e ainda, buscando-se fórmulas que priorizem o processo eletrônico, eliminando o quanto possível o registro de atos processuais em papel;

3. Preenchimento urgente das vagas existentes nos quadros da Magistratura, do Ministério Público e das Defensorias Públicas;

4. Aumento do número de servidores e magistrados nas regiões em que a lentidão processual se mostra mais crítica, por esta razão;

5. Criação da Defensoria Pública nos Estados da Federação que ainda não a possui;

6. Aumento do quadro de servidores e de defensores públicos, de modo a serem oferecidos a toda população necessitada os serviços de assistência 
judiciária integral e gratuita, em todos os ramos do Judiciário e em relação a todas as modalidades de demanda;

7. Imediata oficialização dos cartórios e serventias judiciais e extrajudiciais na Justiça Comum dos Estados, com a criação de quadros administrativos compostos de servidores remunerados pelo poder público, inclusive peritos e oficiais de justiça, com a instituição de um sistema de custas processuais em valores moderados, proporcional ao valor da causa, sem exigência de antecipação de seu pagamento, que deverá ser feito somente depois do trânsito em julgado da sentença, sempre pelo vencido na causa, com isenção a ser concedida aos beneficiários da assistência judiciária gratuita, a exemplo do que já ocorre na Justiça do Trabalho;

8. Ampliação da autonomia financeira dos tribunais, para que possam elaborar seus orçamentos sem a necessidade de concordância dos Poderes Executivo e Legislativo, bem como a instituição de mecanismos que lhes garantam o repasse das verbas orçamentárias, sem diminuições, para atender às suas necessidades, tornando mais rigorosos os processos de controle e fiscalização de sua aplicação;

9. Criação de escolas e cursos de formação e aperfeiçoamento de administradores públicos, de freqüência e aproveitamento obrigatórios para todos os magistrados de segundo grau de jurisdição, como requisito indispensável ao exercício de cargos de dirigentes dos tribunais que integram, bem como aos servidores dos tribunais que exerçam ou venham a exercer cargos de direção ou chefias de secretarias e departamentos;

10. Reformulação do sistema de recursos, racionalizando seu emprego, com diminuição das oportunidades de impugnação aos provimentos jurisdicionais, aplicando-se sanções mais severas e adequadas aos recorrentes, quando ficar demonstrado o uso de recursos com fins meramente procrastinatórios;

11. Instituição de meios coercitivos eficientes para o cumprimento das ordens judiciais, além de multas em quantias elevadas, admitindo-se também a prisão por desobediência, por determinado prazo, mediante certas circunstâncias e preenchimento de requisitos previamente fixados em lei;

12. Revisão da legislação brasileira, com a revogação das normas anacrônicas e em descompasso com a Constituição Federal, adaptando-as às necessidades e a carga axiológica atual da sociedade;

13. Aprovação de um código brasileiro de processos coletivos, tornando o processo meio adequado à solução dos problemas relacionados com os interesses difusos, coletivos e individuais homogêneos. 
14. Implantação e efetivação de políticas públicas, com adoção de medidas adequadas - políticas e econômicas - com o escopo de diminuir os graves problemas sociais brasileiros, como a fome, o desemprego, a insegurança, a falta de moradia e de saneamento básico e as deficiências dos sistemas públicos de saúde e educação, promovendo a inclusão social;

15. Estímulo ao cumprimento espontâneo do ordenamento jurídico pelos particulares e pelo poder público, mediante campanhas publicitárias institucionais voltadas para a população, informando-lhe não apenas da existência dos direitos, mas igualmente dos deveres, e dos meios postos à sua disposição para solução dos litígios, objetivando convencimento de que é importante para a convivência social pacífica e harmoniosa o respeito à lei. Do mesmo modo, mediante disciplina obrigatória nas escolas públicas e privadas a partir do quinto ano do ensino fundamental, além de punição rigorosa para os delitos praticados contra a administração pública e pelos agentes públicos em geral, incluindo os integrantes dos três poderes da República;

16. Diminuição dos casos de jurisdição voluntária e de outros procedimentos de obrigatória apreciação pelo Poder Judiciário, em que não haja litígios a serem resolvidos, com atribuição de competências a agências ou órgãos administrativos; e

17. Incentivo à arbitragem, à conciliação e à mediação, valorizando e legitimando as soluções encontradas pelos interessados, diretamente ou através de terceiros, a exemplo do árbitro e do mediador.

\section{CONCLUSÃO}

O acesso à justiça, visto como direito fundamental, garantido pela Constituição da República, excede aos acanhados limites de mera possibilidade de propor uma demanda perante os órgãos jurisdicionais, devendo ser concebido como acesso aos próprios direitos contemplados pelo ordenamento jurídico substancial e processual, assegurando-se àquele que tem razão a efetiva entrega do bem jurídico tutelado, com o menor custo e tempo possíveis.

Significa acesso a um processo de resultados efetivos, que seja capaz de solucionar a controvérsia projetando seus efeitos na vida das pessoas e nas suas relações. Um processo que produza uma decisão justa, assim entendida aquela que se harmoniza com os valores, princípios e objetivos da ordem constitucional vigente. Importa num sistema que congregue meios materiais e processuais com o condão de proporcionar tutela adequada aos direitos lesados ou ameaçados de lesão. 
Tal postura envolve, necessariamente, o compromisso dos operadores jurídicos em geral, e do juiz em particular, em bem interpretar e aplicar o Direito, sempre tendo como norte a ordem constitucional, portando-se de modo imparcial, mas jamais neutro da perspectiva do Direito justo.

Para a concretização desse direito fundamental faz-se mister a eliminação de barreiras nos âmbitos social, político e econômico, a exemplo da redução das desigualdades sociais, implantação e concretização de políticas públicas, melhoria do sistema de informação à população em geral sobre direitos e deveres, pela correta aplicação dos recursos públicos destinados ao Poder Judiciário, pela formação de administradores públicos no âmbito dos tribunais e pela instalação de núcleos de defensorias públicas em todos os Estados da Federação.

Deve haver preocupação, ainda, com a aproximação entre os órgãos jurisdicionais e os jurisdicionados, a redução das despesas processuais e o aperfeiçoamento de sua disciplina, o aumento e adequada distribuição dos órgãos jurisdicionais (incluindo apropriada estrutura física, informatização e número de magistrados, promotores de justiça, defensores públicos e servidores), a estatização das serventias judiciais e extrajudiciais, a diminuição da litigiosidade do poder público e o incentivo às alternativas não-estatais de solução de controvérsias, como a arbitragem, mediação e conciliação.

\section{REFERÊNCIAS}

BEDAQUE, José Roberto dos Santos. Direito e processo: influência do direito material sobre o processo. 3. ed. rev. ampl. São Paulo: Malheiros Editores, 2003a.

- Tutela cautelar e tutela antecipada: Tutelas sumárias e de urgência (tentativa de sistematização). 3. ed. rev. ampl. São Paulo: Malheiros Editores, 2003b.

BELINETTI, Luiz Fernando. Tutela jurisdicional satisfativa. Revista de Processo, São Paulo, v. 21, n. 81, p. 98-103, jan./mar. 1996.

CAHALI, Yussef Said (Org.). Código Civil, Código de Processo Civil e Constituição da República. 6. ed. São Paulo: Editora Revista dos Tribunais, 2004.

CALMON DE PASSOS, José Joaquim. Instrumentalidade do processo e devido processo legal. Disponível em: 〈http://www.direitopublico.com.br〉. Acesso em: 12 abr. 2006.

CANOTILHO, José Joaquim Gomes. Direito Constitucional e teoria da constituição. 7. ed. Coimbra: Almedina, 2003. 
CAPPELLETTI, Mauro; GARTH, Bryant. Acesso à justiça. Trad. de Ellen Gracie Northfleet. Porto Alegre: Sergio Antonio Fabris, 2002.

CARMONA, Carlos Alberto. A arbitragem no processo civil brasileiro. São Paulo: Malheiros Editores, 1993.

CICHOCKI NETO, José. Limitações do acesso à justiça. Curitiba: Juruá, 2004. DINAMARCO, Cândido Rangel. Instituições de direito processual civil. 3. ed. rev. atual. com remissões ao Código Civil de 2002. São Paulo: Malheiros Editores, 2003. v. 1.

KELSEN, Hans. Teoria pura do direito. Trad. João Baptista Machado. São Paulo: Martins Fontes, 2003.

MESQUITA, Eduardo Mello de. As tutelas cautelar e antecipada. São Paulo: Editora Revista dos Tribunais, 2002. (Coleção Estudos de Direito de Processo Enrico Tullio Liebman; v. 52).

NALINI, José Renato. O juiz e o acesso à justiça. São Paulo: Editora Revista dos Tribunais, 1994.

RAMOS, Glauco Gumerato. Realidade e perspectivas da assistência jurídica aos necessitados no Brasil. São Paulo: Fundação Konrad Adenauer, 2000.

SAMPAIO, José Adércio Leite. Direitos fundamentais: retórica e historicidade. Belo Horizonte: Del Rey, 2004.

WATANABE, Kazuo. Acesso à justiça e sociedade moderna. In: GRINOVER, Ada Pellegrini; DINAMARCO, Cândido Rangel; WATANABE, Kazuo (Coord.). Participação e processo. São Paulo: Editora Revista dos Tribunais, 1988. . Da cognição no processo civil. 2. ed. Campinas: Bookseller, 2000. 